\title{
Eliminative and Reposing Behavior of Dairy Cows in the Stanchion Stall Barn
}

\author{
Denzo Sahara, Tadao Ichikawa*, Yoshiyasu Aihara, \\ Hirofumi KAWANISHI ${ }^{* *}$ and Morimasa NAGASHIMA ${ }^{* *}$ \\ Institute of Agricultural and Forest Engineering, \\ University of Tsukuba, Tsukuba-shi 305 \\ * School of Veterinary and Animal Sciences, \\ Kitasato University, Towada-shi 034 \\ ** College of Agricultural and Veterinary Medicine, \\ Nihon University, Fujisawa-shi 252
}

(Received June 2, 1989)

\begin{abstract}
In order to obtain detailed information on eliminative and lying behavior, observations on nine Holstein cows housed in total confinement in stanchion stalls were made. Behaviors observed included defecation, urination, and lying, and the records were collected by visual observations for 24 consecutive hours on each of the 3 occasions. Average values of the behavioral observations were summarized as follows : frequency of defecations and urinations were $9.0 \pm 2.5$ and $4.3 \pm 2.2$ times with ranges of 5.3 to 12.0 and of 2.3 to 8.0 , respectively. The times required for elimination by defecation and by urination were $7.6 \pm 2.6$ and $11.7 \pm 5.5 \mathrm{~min}$, with ranges of 6.1 to 10.5 and 7.7 to $19.8 \mathrm{~min}$, respectively. The frequency of periods lying down, total duration of lying, and duration per lying were $11.8 \pm 6.5$ (range 2 to 21 ), $625.6 \pm 166.4 \mathrm{~min}$, (range 398 to 807 ) and $53.5 \pm$ $51.5 \mathrm{~min}$, (range 24.3 to 212.3), respectively. The average intervals between defecations, between urinations and between lyings were $160.8 \pm 99.6 \mathrm{~min}, 335.2 \pm 245.3 \mathrm{~min}$, and 69.6 $\pm 12.1 \mathrm{~min}$, respectively. Significant differences were found between the day-time $\left(8: 00^{-}\right.$ $20: 00)$ and the night-time $(20: 00-8: 00)$ in all recorded behavioral data except the time required for defecation and the interval between defecations.
\end{abstract}

Jpn. J. Zootech. Sci.,61 (3) : 249-254, 1990

About half of the management time spent for dairy cows in the barns is for the milking routine. Therefore, milking efficiency holds the key to the rationalization of management. Cleanliness of the udder contributes greatly in reducing the length of time for milking chores because the time required to wash the udder before milking is determined by the degree of udder contamination. In fact, it has been reported that the design of the stall structure, including gutter structure, affects the time spent for udder preparation ${ }^{1}$.

To rationalize dairy herd management so Jpn. J. Zootech. Sci., 61 (3) : 249-254 that it ensures that the cow keeps the udder clean requires detailed information on the eliminative and lying behavior of dairy cattle. This paper deals with eliminative behavior, including defecation and urination and with lying behavior of dairy cattle housed in stanchion stalls.

\section{Materials and Methods}

Nine Holstein cows in dry stage were housed in stanchion stalls, each with a floor length of $1,600 \mathrm{~mm}$. The cows averaged 8.8 years of age and $601 \mathrm{~kg}$ of weight. All cows were fed twice 
each day (concentrate of $2 \mathrm{~kg}$, timothy grass hay of $2 \mathrm{~kg}$, potato of $2 \mathrm{~kg}$, and green maize of $17 \mathrm{~kg}$ per head per meal). Water was provided ad libitum by water cups. Records of defecation, urination, and lying were collected by visual observation. The nine cows were observed for 24 consecutive $\mathrm{hr}$, on each of the 3 occasions during September and August of 1988 resulting in a total of 27 animal-observations. The mean values of data were compared by the t-test for significant differences between data of the day-time $(8: 00-20: 00)$ and the nighttime $(20: 00-8: 00)$.

\section{Results and Discussion}

1. Frequency of elimination

The cows averaged $9.0 \pm 2.5$ defecations, with a range of 5.3 to 12.0 times, and $4.3 \pm 2.2$ urinations, with a range of 2.3 to 8.0 times, and the average intervals between defecations and between urinations were $160.8 \pm 99.6 \mathrm{~min}$, and $335.2 \pm 245.3 \mathrm{~min}$, respectively (Table 1 ).

There had been several reports on frequency of cow elimination. Defecation of 13.6 times per day was recorded by Mitsumata et al. ${ }^{2}$, using three Holstein milking cows, and 13.9 times by Suzuki et l. $^{3}{ }^{3}$, using 16 Holstein milking cows, both under housing conditions. On the other hand, the number of 8.13 defeca- tions was found by GRAY et al. ${ }^{4)}$ under grazing condition with Charolais cows.

It is apparent that feeding conditions influence the frequency of defecation; our values, however, were between those of the two different conditions. Differences between ours (housed) and the former two (housed) may be due to whether the cattle used were dry cows or milking cows which might influence the amount of feed intake and the state of feed, mainly moisture content. SuzuKI et al. ${ }^{3)}$ observed defecation of 5.1 times when cows received only concentrate mixture and hay during their dry period, but defecation of 11.3 times was recorded when they were fed on green grass during their lactation period. In our observations, cows averaged 9.0 defecations of which $5.2(58 \%)$ were during the day-time and $3.8(42 \%)$ were during the night-time, respectively, and the difference was statistically significant $(\mathrm{P}<0.01)$.

The average interval between defecations was $160.8 \pm 99.6 \mathrm{~min}$, and there was no significant difference between the day-time interval and the night-time interval.

The values of $2.3^{2)}, 5.1$ (with a range of 2$10^{5}$ ), 6.4 (with a range of $2-20^{3}$ ), and $6.2^{4)}$ of urination have been reported.

In our data, the average frequency of urina-

Table 1. Average values of eliminative behavior

\begin{tabular}{|c|c|c|c|c|}
\hline & • & $\begin{array}{l}\text { Frequency } \\
\text { (No.) }\end{array}$ & $\begin{array}{l}\text { Time required } \\
(\mathrm{sec})\end{array}$ & $\begin{array}{c}\text { Interval } \\
\text { (min) }\end{array}$ \\
\hline \multirow{5}{*}{ Defecation } & Average & $9.0 \pm 2.5$ & $7.6 \pm 2.6$ & $160.8 \pm 99.6$ \\
\hline & Range & $5.3 \sim 12.0$ & $6.1 \sim 10.5$ & $104.0 \sim 381.8$ \\
\hline & Day-time & $5.2 \pm 1.6$ & $7.5 \pm 2.7$ & $145.4 \pm 96.0$ \\
\hline & Night-time & $3.8 \pm 1.5$ & $7.7 \pm 2.4$ & $181.9 \pm 100.6$ \\
\hline & $\begin{array}{l}\text { Difference } \\
\text { between day-time } \\
\text { and night-time }\end{array}$ & $1.4^{* *}$ & -0.2 & -36.5 \\
\hline \multirow{5}{*}{ Urination } & Average & $4.3 \pm 2.2$ & $11.7 \pm 5.5$ & $335.2 \pm 245.3$ \\
\hline & Range & $2.3 \sim 8.0$ & $7.7 \sim 19.8$ & $127.6 \sim 900.5$ \\
\hline & Day-time & $2.9 \pm 1.8$ & $9.8 \pm 3.8$ & $276.7 \pm 218.1$ \\
\hline & Night-time & $1.4 \pm 0.8$ & $15.5 \pm 6.4$ & $450.6 \pm 257.7$ \\
\hline & $\begin{array}{l}\text { Difference } \\
\text { between day-time } \\
\text { and night-time }\end{array}$ & $1.5^{* *}$ & $-5.7^{* * * *}$ & $-173.9^{*}$ \\
\hline
\end{tabular}

*** $\mathrm{P}<0.001,{ }^{* *} \mathrm{P}<0.01,{ }^{*} \mathrm{P}<0.05$ 


\section{Elimination and Repose of Dairy Cows}

tion was 4.3 , of which 2.9 times $(67 \%)$ occurred during the day-time and 1.4 times (33\%) occurred during the night time, respectively, and the difference was again statistically significant $(\mathrm{P}<0.01)$.

The average interval between urinations was $335.2 \pm 245.3 \mathrm{~min}$, and the difference between the day-time and the night-time was also statistically significant $(\mathrm{P}<0.05)$.

Fig. 1 and 2 show the hourly distribution of defecation and urination, respectively, during

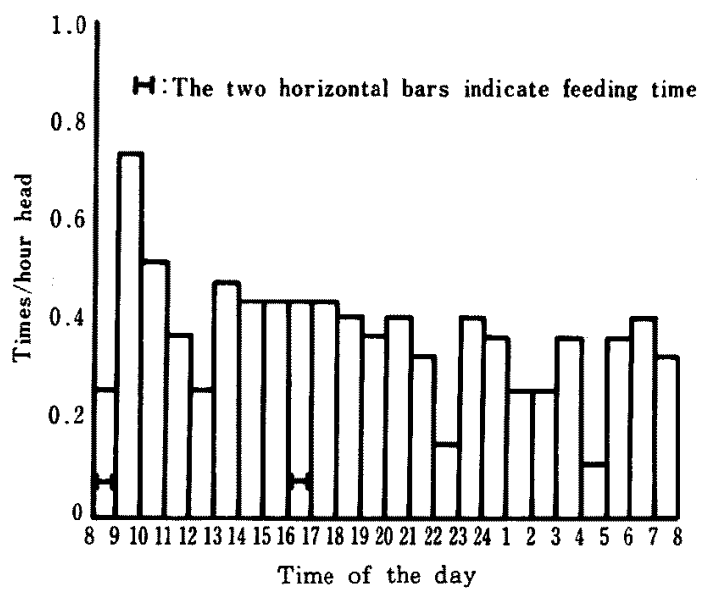

Fig. 1. Hourly distribution of number of defecations (Average of 27 cows)

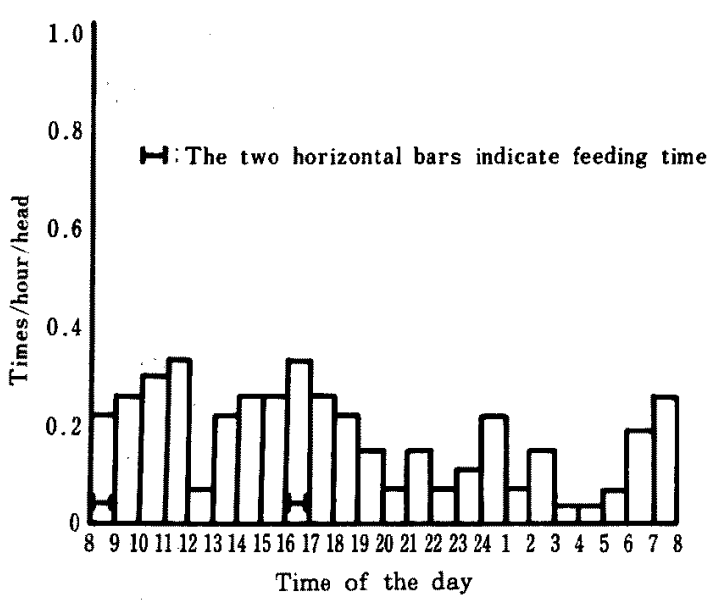

Fig. 2. Hourly distribution of number of urinations (Average of 27 cows)
$24 \mathrm{hr} .$. It is likely that defecation had no special influence on the pattern of behavior, however, the most intense periods of urination occurred immediately after the AM and PM feeding times. And low frequencies of both defecation and urination were recorded between $3: 00$ and $5: 00$ in the morning. It was clear that cows have significantly less defecation and urination during the night-time than during the day-time, and the interval between urinations during the night-time was longer than that during the day-time.

2. Time required to eliminate

Times required for defecation and urination also appear in Table 1. The average times required for defecation and urination were 7.6 $\pm 2.6 \mathrm{sec}$, and $11.7 \pm 5.5 \mathrm{sec}$., with ranges of 6.1 to $10.5 \mathrm{sec}$, and of 7.7 to $19.8 \mathrm{sec}$, respectively. There was no special tendency according to time of day of defecation, but cows seemed to spend relatively longer times for urination during the period from mid-night to early morning (Fig. 3 and 4). This may be related to the fact that frequency of urination was relatively low, compared with defecation, during the same hour period.

The average time of $15.5 \mathrm{sec}$, for the nighttime was significantly $(\mathrm{P}<0.001)$ longer than that of $9.8 \mathrm{sec}$, for the day-time.

3. Lying behavior

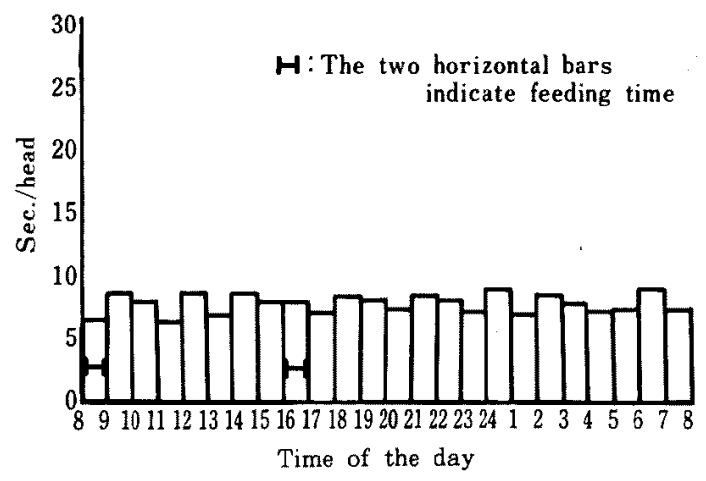

Fig. 3. Hourly distribution of time (sec) spent on defecation (Average of 27 cows) 
Sahara, Ichikawa, Aimara, Kawanishi and Nagashima

Table 2. Average values of lying behavior

\begin{tabular}{lcccc}
\hline & $\begin{array}{c}\text { Frequency of periods } \\
\text { (No.) }\end{array}$ & $\begin{array}{c}\text { Total time per } 24 \mathrm{~h} \\
\text { (min) }\end{array}$ & $\begin{array}{c}\text { Duration per period } \\
\text { (min) }\end{array}$ & $\begin{array}{c}\text { Interval } \\
\text { (min) }\end{array}$ \\
\hline Average & $11.8 \pm 6.5$ & $625.6 \pm 166.4$ & $53.5 \pm 51.5$ & $69.6 \pm 12.1$ \\
Range & $2.0 \sim 20.7$ & $398.0 \sim 906.7$ & $24.3 \sim 212.3$ & $14.2 \sim 507.7$ \\
Day time & $4.4 \pm 3.2$ & $154.6 \pm 93.3$ & $35.4 \pm 34.1$ & $106.2 \pm 126.8$ \\
Night time & $7.3 \pm 3.8$ & $471.1 \pm 123.3$ & $64.2 \pm 57.0$ & $46.0 \pm 128.4$ \\
$\begin{array}{l}\text { Difference } \\
\text { between day-time }\end{array}$ & $-2.9^{* * *}$ & $-316.5^{* * *}$ & $-28.8^{* * *}$ & $60.2^{* * *}$ \\
and night-time & & & & \\
\hline$* * *$ P<0.7 & & & & \\
\hline
\end{tabular}

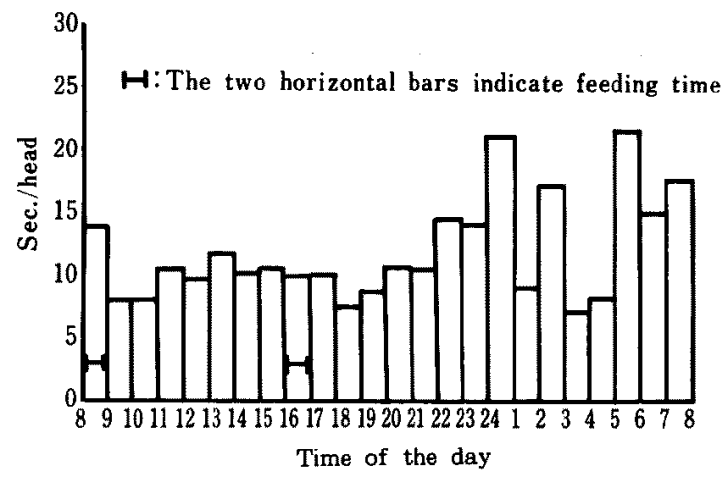

Fig. 4. Hourly distribution of time (sec) spent on urination (Average of 27 cows)

Table 2 shows that the average frequency of periods of lying, total time of lying per $24 \mathrm{hr}$, and average duration of lying were $11.8 \pm 6.5$ times (range 2 to 21$), 625.6 \pm 166.4 \mathrm{~min},(398.0$ to 806.7 ) and $53.5 \pm 51.5 \mathrm{~min}$, (24.3 to 212.3 ), respectively.

There was an apparent disproportion between the data of the day-time and of the nighttime : cows were usually recumbent a shorter duration of $2.57 \mathrm{hr},(21.7 \%)$ during the daytime, while they rested a longer duration of $7.85 \mathrm{hr},(65.4 \%)$ during the night-time. The same disproportion was found in frequencies of lying : out of an average number of 11.8 periods of lying during $24 \mathrm{hr}$, about $38 \%$ was recorded during the day-time, and $62 \%$ occurred during the night-time. Average durations per lying also were disproportionate : $35.4 \pm$ $34.1 \mathrm{~min}$, was recorded during the day-time; on the other hand $64.2 \pm 57.0 \mathrm{~min}$, during the

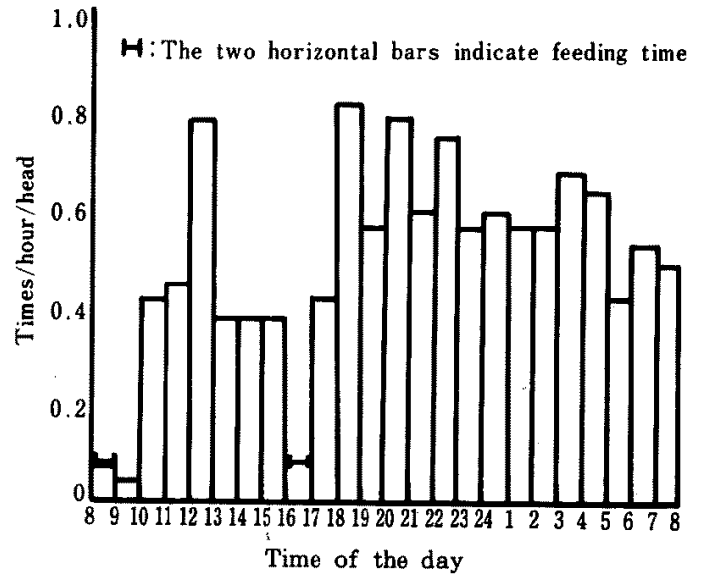

Fig. 5. Hourly distribution of number of lying (Average of 27 cows)

night-time.

The average interval between lyings was $69.6 \pm 12.1 \mathrm{~min}$, (range 14.2 to $507.7 \mathrm{~min}$ ), and the same disproportion was found : $106.2 \mathrm{~min}$, for the day-time and $46.0 \mathrm{~min}$, for the nighttime.

All the above differences between the daytime and the night-time were statistically significant $(\mathrm{P}<0.001)$.

Hedlund et al. ${ }^{6)}$ reported that stanchionstalled cows lay an average of $10.3 \mathrm{hr} / 24 \mathrm{hr}$ day (range 4.8 to $15.0 \mathrm{hr}$ ). Several other reports indicated that cows spent $8.7 \mathrm{hr}$, (range 9 to $13 \mathrm{hr}$ ) lying in pasture ${ }^{4}$, but 11 to $11.5 \mathrm{hr}$ in loose or free stall housing ${ }^{7,8)}$. HEDLUND et al. ${ }^{\text {) }}$ also found that during the day-time cows averaged about nine periods of recumbency and an equal number of rest periods at 


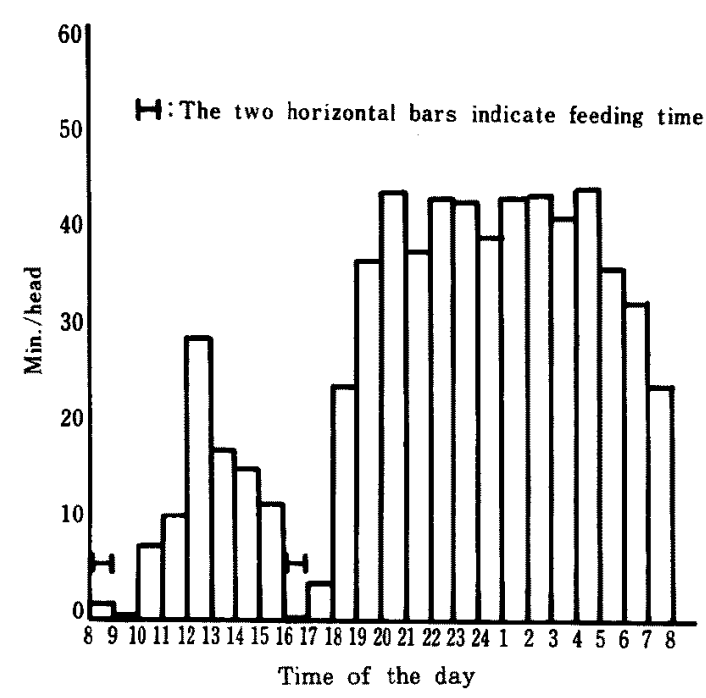

Fig. 6. Hourly distribution of time (min) spent on lying (Average of 27 cows)

night to give an average total of 18 to 20 rest periods per $24 \mathrm{hr}$, day, and that the cows were recumbent an average of 5.5 of $9 \mathrm{hr}$, of darkness and 6.6 of $15 \mathrm{hr}$, of light. Our data, however, showed that the average frequency of periods and total duration of lying during the day-time $(12 \mathrm{hr}$ ) was less than that during the night-time $(12 \mathrm{hr}$, ), i.e., $4.4 \pm 3.2$ vs $7.3 \pm 3.8$ times, and $21.7 \%$ vs $65.4 \%$ of each $12 \mathrm{hr}$, And as shown in Fig. 5 and 6 frequent lying and standing actions of cows were recorded during $19: 00$ and $6: 00$, and periods of lying were relatively longer during the same hours.

It is assumed that the cow's udder is more easily soiled during night-time because the longer time of rucumbency and more frequent lying are obvious from our results. It is expected that our findings give farmers, advisers and engineers useful information to rationalize dairy herd, management to ensure keeping the udder cleaner.

\section{Acknowledgment}

The assistance of the staff smembers of the farm, The Agricultural and Forestry Research Center, University of Tsukuba is gratefully acknowledged.

\section{References}

1) Sahara, D., Y, Aihara, T. Ichikawa, H. KaWANisur and M. Nagashima, A Study on Work Efficiency in Udder Preparation of Milking CowsEffects of Structure of Manure Gutter on Udder Preparation Time and Cleanliness of Udder- (in Japanese). J. Soc. Agri. Structure, Jpn., 19 : 107-112. 1988.

2) Mitsumata, N., N. Tanaka, Y. Yamashita and A. MiYASHITA, Recording Method of Behavior of Cattle by Pasturing and Barn-feeding (Japanese). J. Japan. Grassl. Sci., 9 : 77-82. 1964.

3) SuzUki, S., Y. Shinde, K. Yoshi and Y. Takimoto, Studies on the Eliminative Behaviour of Dairy Cows (in Japanese). Res. Bull Obihiro Univ., 5 : 45-54. 1967.

4) Gray, L. A., G.W. Sherritt and E. B. Hale, Behavior of Charolais cattle on Pasture. J. Anim. Sci., $30: 203-205.1970$.

5) OHNo, W. and A. TANAKA, Studies on Action of Dairy Heifer during Pasturing, (1) On Seasonal Change of Action of Heifer Herd (in Japanese). J. Japan. Grassl. Sci., 11:132-137. 1965.

6) Hedlund, L., L. HahN, G. Thomas and H.D. JoHnson, The Effect of Flies on Body Movement of Dairy Cows. J. Anim. Sci., 35 : 166. 1972.

7) Friend, T.H. and C.E. Polan., Social Rank, Feeding Behavior, and Free Stall Utilization by Dairy Cattle. J. Dairy Sci., 57 : 1214. 1974.

8) Schmisseur W.E., J.L. Albright, W.M. Dillon, E.W. Kehrberg and W.H.M. Morris, Animal Responses to Loose and Free Stall Housing. J. Dairy Sci., 49 : 102.1966.

9) Hedlund, L. and J. Rolus, Behavior of Lactating Dairy Cows during Total Confinement. J. Dairy Sci., 60 : 1807-1812. 1977. 


\section{スタンチョン式牛舎の乳牛の排せつならびに横臥行動 \\ 佐原傅三・市川忠雄 ${ }^{*}$ 相原良安・川西啓文 ${ }^{* *} \cdot$ 長島守正 ${ }^{* *}$ \\ 筑波大学農林工学系，つくば市 305 \\ * 北里大学 獣医畜産学部, 十和田市 034 \\ ** 日本大学農獣医学部，藤沢市 252}

乳牛の乳房を出来るだけ污さない合理的な乳牛の管理法を確立するために，9頭の非搾乳牛を用いて， 舎飼時の排せつおよび横臥行動を調べた，観察は 24 時間にわたって行ない，これを 3 回綝り返し実施 した．のべ 27 頭の測定値の平均と範囲は以下のとおりであった。排葓および排尿回数（範囲）は，1 日当たりそれぞれ $9.0 \pm 2.5$ 回（5.3〜12.0）および $4.3 \pm 2.2$ 回（2.2〜8.0）で，両者之あ夜間は昼 間より回数が有意に少なかった。 また，1 回当たりに要した時間は，それぞれ $7.6 \pm 2.6$ 秒く $6.1 〜$ 10.5) および $11.8 \pm 5.5$ 秒（7.7 19.8）で, 排尿は排䔬より明らかに所要時間が長かった。 また, 夜 間は昼間より有意に長い傾向が琶められた。一方，1日当たりの横卧回数およびのべ横卧時間は 11.8 士6.5回（2〜21）および $625.6 \pm 166.4$ 分（398.0 806.7）であった.また, 横臥 1 回当たりの時間 は $53.5 \pm 51.5$ 分（24.3 212.3）であった．横臥は，回数，延べ時間および 1 回当たりの時間ともに 夜間は昼間よりその值が有意に大きく，また横臥と横臥との間隔は平均 $69.6 \pm 12.1$ 分で, 昼間のそれ は夜間より有意に長かった。これらのことが朝夕の摧乳時の乳房の污れ程度に大きく関与しているもの と思われた。

日畜会報, 61 (3)：249-254，1990 